\title{
Cold steel supraglottoplasty for severe laryngomalacia in infants
}

\author{
Soorya Pradeep (10 , Arun Alexander
}

ENT, Jawaharlal Institute of Postgraduate Medical Education and Research, Puducherry, India

Correspondence to Professor Arun Alexander; arunalexandercmc@gmail.com

Accepted 29 June 2021
Check for updates

(C) BMJ Publishing Group Limited 2021. No commercial re-use. See rights and permissions. Published by BMJ.

To cite: Pradeep S,
Alexander A. BMJ Case
Rep 2021;14:e242663.
doi:10.1136/bcr-2021-
242663

\section{DESCRIPTION}

A 9-month-old female baby was brought to the emergency room (ER) by her parents with reports of noisy breathing, poor feeding, inadequate weight gain and intermediate cyanotic spells noticed for the past month. She was a full-term baby weighing $2.8 \mathrm{~kg}$ at birth and had no other comorbidities.

On examination, the baby was malnourished, weighing $7 \mathrm{~kg}(<15$ th percentile of weight for age). She was afebrile but had tachypnoea and tachycardia. She displayed severe suprasternal and subcostal chest retractions. She also had inspiratory stridor, which decreased in intensity on holding her in a prone position. On auscultation, she had bilateral normal vesicular breath sounds.

Transnasal flexible laryngoscopy showed an omega-shaped epiglottis with shortened aryepiglottic folds, mobile vocal cords and a normal subglottis (figure 1). She was diagnosed to have severe laryngomalacia necessitating surgical intervention.

She underwent endoscopic cold steel supraglottoplasty under total intravenous anaesthesia and spontaneous ventilation (refer video 1). The shortened aryepiglottic folds were snipped using microlaryngeal scissors, and the baby was kept intubated for 24 hours postoperatively. The immediate postoperative period was uneventful, with improvement in stridor and chest retractions. She was discharged on the age-appropriate dose of proton pump inhibitors, and her mother counselled regarding breastfeeding techniques to minimise regurgitation. She was kept on regular follow-up, and her weight was monitored weekly.

At 3-month follow-up, the baby had no stridor and or chest retractions. She had had no further cyanotic episodes, her feeding had improved and she had achieved significant weight gain. She had gained

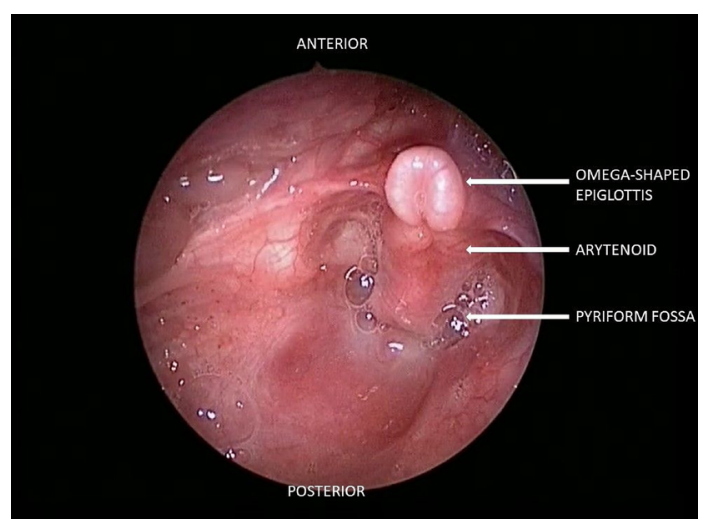

Figure 1 Endoscopic view of the endolarynx demonstrating laryngomalacia.

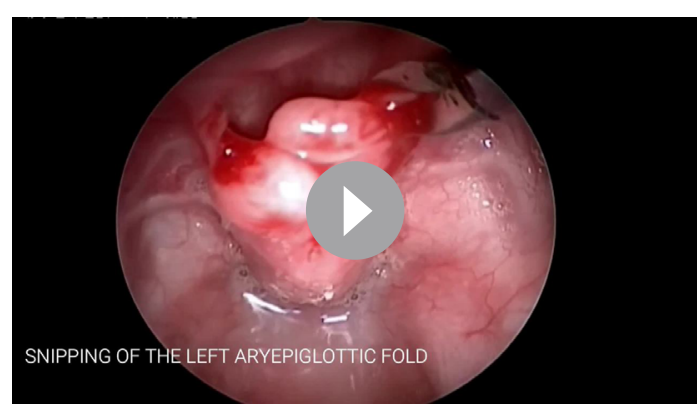

Video 1 Cold steel supraglottoplasty for severe stridor in infants

$2 \mathrm{~kg}$ over 3 months, bringing her weight to $9 \mathrm{~kg}$, although her weight was still less than that expected of her age (between the 15th and 50th percentile of weight-for- age).

Laryngomalacia is the most common cause of stridor in infancy. ${ }^{1}$ It is a congenital anomaly believed to occur due to the inward collapse of the supraglottis during inspiration. The diagnosis is usually made based on the high-pitched fluttering inspiratory stridor that improves when the child is held in a prone position and confirmed by transnasal flexible laryngoscopy, which shows a characteristic omega-shaped epiglottis and inward collapse of the supraglottis on inspiration. Most cases of laryngomalacia are mild and self-limiting, with the symptoms resolving at around 12-24 months of age. Only severe laryngomalacia $(15 \%)$ characterised by difficulties in feeding, obstructive sleep apnoea, failure to thrive and cyanotic spells requires surgical intervention. ${ }^{1}$ The mainstay of surgical intervention is supraglottoplasty. Supraglottoplasty refers to the excision of redundant tissue to open up the airway, which may be achieved using either microlaryngeal instruments

\section{Learning points}

- Laryngomalacia is the most common cause of inspiratory stridor in infants-also consider the possibility of bilateral abductor palsy, posterior glottic cleft, subglottic stenosis/haemangioma.

- The diagnosis may be confirmed by awake transnasal flexible laryngoscopy.

- Only severe laryngomalacia requires surgical management-the mainstay of treatment is supraglottoplasty.

- While supraglottoplasty using a carbon dioxide laser is widely used, cold steel supraglottoplasty is an equally efficacious alternative in resourcepoor countries. 
(cold steel supraglottoplasty) or using a carbon dioxide laser. Laser supraglottoplasty is believed to have better precision but is associated with the inherent risk of airway fires, laryngeal oedema and aspiration from thermal damage to supraglottic sensory receptors. ${ }^{2}$ It also requires appropriate infrastructure (a laser operation theatre (OT), laser safe endotracheal tube, laser technician), which is more expensive and time-consuming. ${ }^{2}$ In resource-poor settings, cold steel supraglottoplasty is a viable and efficacious alternative.

Contributors AA: collected data, edited the manuscript. SP: wrote the manuscript. Funding The authors have not declared a specific grant for this research from any funding agency in the public, commercial or not-for-profit sectors.
Competing interests None declared.

Patient consent for publication Parent/guardian consent obtained.

Provenance and peer review Not commissioned; externally peer reviewed.

\section{ORCID iDs}

Soorya Pradeep http://orcid.org/0000-0003-4164-127X

Arun Alexander http://orcid.org/0000-0003-1026-4678

\section{REFERENCES}

1 Monnier P. Pediatric airway surgery. Lausanne, Switzerland: Springer, 2010.

2 Richter GT, Thompson DM. The surgical management of laryngomalacia. Otolaryngol Clin North Am 2008;41:837-64.

Copyright 2021 BMJ Publishing Group. All rights reserved. For permission to reuse any of this content visit

https://www.bmj.com/company/products-services/rights-and-licensing/permissions/

BMJ Case Report Fellows may re-use this article for personal use and teaching without any further permission.

Become a Fellow of BMJ Case Reports today and you can:

- Submit as many cases as you like

- Enjoy fast sympathetic peer review and rapid publication of accepted articles

- Access all the published articles

Re-use any of the published material for personal use and teaching without further permission

\section{Customer Service}

If you have any further queries about your subscription, please contact our customer services team on +44 (0) 2071111105 or via email at support@bmj.com.

Visit casereports.bmj.com for more articles like this and to become a Fellow 